（3）(2)の結果のように、積睤】ォームの“硬さ”は， $Z\left(Y_{B}, Y_{l}\right)$ で示され，掅層フォームの王縮モシュラス

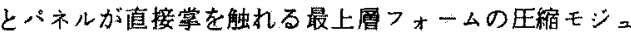
ラスの雨特性の支配をうけるが。判别関数の各量の係数 から， $Y_{t} よ り Y_{B}$ のほらが積層フォ一ムの“硬さ”人の寄 与は大きいことがわかる。

最後に，本稿のご高閲を賜わりました，京都工芸䋐維 大学井上友一教授ならびに若山一夫教授に深謝致します。
文南

1)大村、若山，井上; 䄉学誌，25，248（1969)

2) 大村, 若山, 井上; 緎学誌，26，23(1970)

3) 大村；䋞学誌，31，T111(1975)

4) 大村；緎学誌，31，T221(1975)

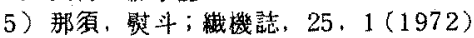

6) 小林，緎学誌，25，223(1969)

7) 布の屈合い編集委員会編；「布の風合い」(䄉機学 会) (1972)

(昭和 50 年 3 月 22 日受理)

\title{
分繊ローラーによるスライバの分離
}

\author{
岐阜大学工学部近田冨士雄 - 黒崎新也 \\ 横井輝之 \\ 滋賀㝠立短期大学 伊 藤 元 貴
}

\section{SEPARATING SLIVER INTO SMALL FIBER ASSEMBLIES USING OPENING DEVICE WITH COMBING ROLLER}

\author{
By Fujio Konda, ${ }^{*}$ Shinya Kurosaki, ${ }^{*}$ Teruyuki Yokoi ${ }^{*}$ and Motoyoshi Ito** \\ * (Faculty of Engineering, Gifu University, Kakamigahara City, Gifu Prefecture, Japan) \\ ** (Shiga Prefectural Junior College, Hikone City, Shiga Prefecture, Japan)
}

The sliver was separated into small fiber assemblies using opening device with combing roller as well as air suction, and then the effects of sliver thickness, input roller speed, surface speed of combing roller, and air velocity on the weight of separated fiber assemblies were studied.

The sliver having periodic irregularity was separated, and the weights of fiber assemblies were detected and recorded continuously. The variations in their weight were statistically analysed into auto and cross correlation functions.

The results obtained are as follows:

(1) In the case of using both combing roller and air suction, the weights and their variations are smaller than when only air suction is used.

(2) The thicker the input sliver is, the greater the weight of separated fiber assemblies becomes. The surface speed of feed roller makes the same effect as the thickness of input sliver. (Fig. 3, Fig. 4)

(3) Though the surface speed of combing roller has little effect on the weight of separated fiber assembly, the velocity of suction air has greater effect on it. (Fig. 5, Fig. 6)

(4) Separating sliver generates the additional random variation on the output, so relatively the ratio of periodic variation to total variation decreases, especially by using opening device without combing roller works effectively. (Fig. 11)

(Received March 22, 1975)

\section{1. 緒言 \\ オープンェンド精紡に括てい，スライバの分紻は必須} の操作である。現在採用さ九ている分緎装置は分絨口ー
ラーで開繶し，吸引気流によって分離・移送するものが 多い。理想的な分絨は䋘維の切断・損傷を少なくし，し かも1本ずつに分離し，折れ曲りの少ない状態で輸送す ることでる。 
従来，分緎過程の奏験的研究 ${ }^{1 \sim 9)}$ は少なく，とくに分 離瀻維集団の連統的測定上供給スライパの太さむらの関 係については究明されていない。我々はすでに前報 ${ }^{1} に$ おいて，分離緎維集団の重量を連続的に唡出・記䩮する 装膡を作整し，これを用いて吸引気流のみによる単純分 截について報告した。とくに，供給スライハの太さむら と分離緎維集団の重量の時間的変化について，それぞれ の自己相関関数，および相互相関関数を計算し，分離の 特性を示した。

本報は前報りと同じ方法により，分䋐ローラ一を適用 した場合における分離について解明寸る。すなわち、ス ライバの供給速度，スライパ太さ，分䄉ローラーの回転 数，吸引気流の速度が分雄に及ぼす影䇾を明らかにする。 また，供給スライパの太さむらと分離の関係について解 析し，単純分襍のみによる結果と比較検討する。

\section{2. 実験装置およひ実験方法}

图1(A)は供給ローラーから送り出されたスライパを そのまま吸引気流によって分離する装直である。以後， 因1（A）による方法を単純分離と称する。供給口ーラ一 のニッブから吸引管入口まての距離は $3 \mathrm{~cm}$ です,吸引 管の内径は $15 \mathrm{~mm}$ である。供給速度は $0.1 \sim 25 \mathrm{~cm} / \mathrm{sec}$ の範用を任意に選ぶことができる。四 1(B)はコーミン グローラーによって開緎分﨎する装膡である。供給口ラーによって送り出されたスライバは高速て回転する分 織ローラーによって開瀻される。つぎに，分緎ローラー 表面上の瀻䧽は吸引気流によって剝雄され，輸送管内を 移動する。分織装着に近接した部分に，光電的方法によ って分離㵶維集団の大きさを連繹的に検出する装監を設 圈した。この装直は前報りで詳述したので省略する。供 給ローラーの径は $25 \mathrm{~mm}$ であり，供給速度を $0.1 \sim 10 \mathrm{~cm}$ secに变えることが可能である。また，分㵶ローラーの 佳は $100 \mathrm{~mm}$ ，幅は $30 \mathrm{~mm}$ でり，回転数は600〜6000 rpmの籍曲を任意に選ぶことが可能である。分瀻口ー ラーに巻かれたィタリックワイヤの形状を図1(C)に示 す。なお，分瀻ローラーから織維の剝崔を良好にする゙ ために補助空気流の取入口○を設けた。本研究では，ワ イヤ形状，ケーメと分紻ローラーのゲージ，吸引空受㽬 等の実用的条件について究明されていない。吸引風速は (A) (B)いずれも $20 \sim 120 \mathrm{~m} / \mathrm{sec} の$ 範眫内で任意に 設定することができる。

試料は $2 \mathrm{D}, 51 \mathrm{~mm}$ カットのビスコースレーヨンより なる種なの太さの練条 3 回上りスライハである。また， 供給スライバの太さむらと分離の関係を調心゙る場合には, ドラフト装店のフロントコントローラーの表面速度を正 弦波状に変化させ，波長を $10 \mathrm{~cm}$ と一定にし，振幅が平

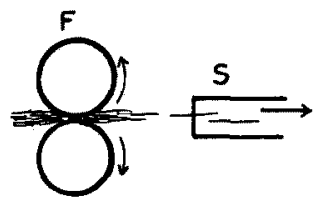

(A)

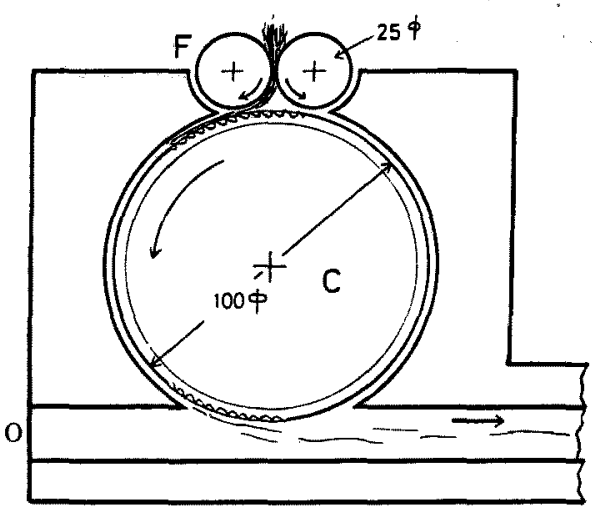

(B)
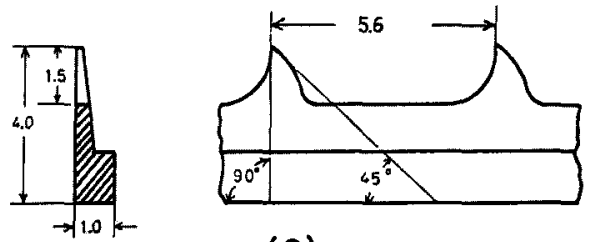

(C)

Fig. 1 (A) Sliver opening device only with air suction $S$ : Suction pipe

(B) Sliver opening device with combing roller and air suction

$\mathrm{F}$ : Feed roller $\mathrm{C}$ : Combing roller

(C) Toothed wire

均太さに対して士 $30 ， 26 ， 22 ， 15 ， 12 \%$ と異なる周期む らをもつスライバを作成した。CV名で示すと，それぞれ $23.4 ， 19.7,16.9,12.6,9.7 \%$ \%あるさらに、波長の 影辢を調べるために，振幅が平均太さに対して士30\%と 一定て，波長が9，13，17 cm と異なるものを作成した。 なお，分離に大きな影橥を及ぼすと考えられる平行度に ついて检討した結果，太さむらに対応した場所的な差は ほとんど認められなかっった。

\section{3. 奏験結果亡考察}

\subsection{2 .3 の分縺条件が分踓維維集団の重量に及 ぼす影䇾}

図 2 は単純分離と分織ローラーによる場合の分㵶状態 

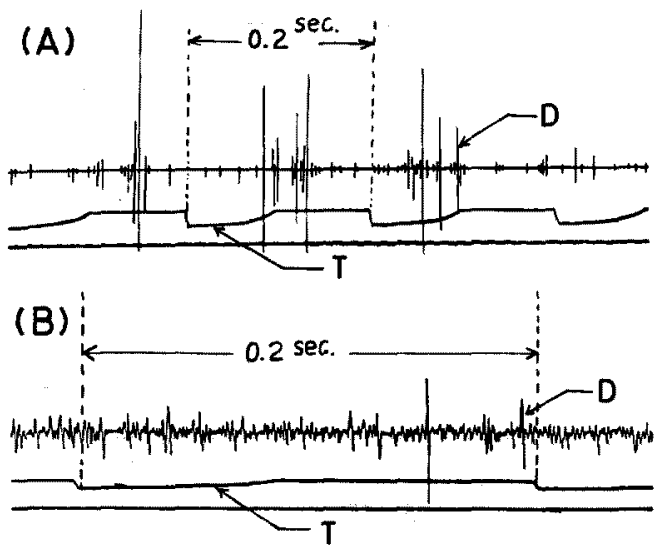

Fig. 2 Examples of recorded signals.

(A) Results without combing roller

(B) Results with combing roller

$D$ : Signal from detector $T:$ Time

を記録した結果の例を示す。(A)は単純分離の場合，(B) は分緎ローラーを設置した場合である。（Ｂ）は（Ａ）に比 船して感度を 5 倍，時間軸老 2.5 倍に拆大して記録した。 単純分離の場合は単位時間に分離する個数柱少なく，し かも小さな集団から大きな集団まで存在し，変動が大き い。これに対して分緘ローラーによる結果は数多くの比 较的細加い集団に分離している。スライバ太さ，供給速

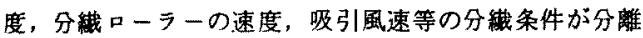
織維集団の大きさに及ぼす㷧響を調べるために，それぞ れの記録結果からパルスの高さを読み，分離掝維集団の 重量の平均値, 変動を計算した。

図3(A)は横軸にスライバ太さ，縦軸に1個当りの分

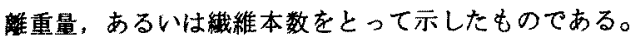
供給口ーラーの表面速度は $0.024 \mathrm{~m} / \mathrm{sec}$, 分緎ローラー の表面速度法 $17.26 \mathrm{~m} / \mathrm{sec}$, 吸引風速は $117 \mathrm{~m} / \mathrm{sec}$ と 一定にした。分絨口ーラーの場合と単純分離の結果を比 較して示したが，いずれも供給スライバが太くなるにつ

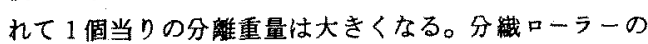
婸合は単純分離に比較して約 $1 / 10$ となり、スライ仿 細い場合には1２本程度まで細汃く分離している。

供給口ーラーの表面速度と分䄉口ーラーの表面速度比 でスライバが細くされるとして断面琙維本数を計算した 結果を医線 $L_{1}$ で表わす。すなわち， $L_{3}$ は分䄉ローラー 上での断面轹維本数を示す。分維口ーラーの表面速度よ りも吸引気流の速度の方が大きいため分緎ローラー上の 鿁䧽は虽離によってさらに紏かくなる。一方， $L_{1}$ のもの がさらに吸引気流の速度で細くなると仮定した場合の断 面溨維本数を $L_{2}$ で示す。現実のスライバはむらを有し ており，また完全に 1 本ずつ分離しないことから， $L_{2}$ よ
りも大きく，L、よりも小さい值をとる実験結果が理解さ れる。

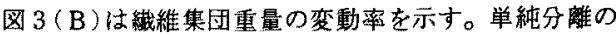
場合は変動率も大きく，太さに対して增加の㑯向を示す が，分䋘口ーラーを用いた場合は50\%程度で太さに対し て影著な增加は認められない。

図 4 牥分織口ーラ一の表面速度を $17.26 \mathrm{~m} / \mathrm{sec}$ ，吸 引風速を $117 \mathrm{~m} / \mathrm{sec}$ と一定にし，供給口ーラーの表面 速度を変化させた場合の結果である。供給ローラーの表 面速度の変化は供給スライバ太さ変化と同じであり，四 3(A)と同梯な傎向を示す。

図 5 は分紻ローラーの表面速度の影䇾を示したものて ある。スライぐ番手は 1060 Tex，供給口ーラーの表面

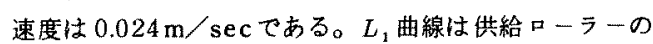
表面速度と分䄉口ーラーの表面速度比加求的た計算曲 線てあり，一方直線 $L_{2}$ は供給ローラーの表面速度と吸引 気流の速度比から求めたものである。図より分緎ローラ

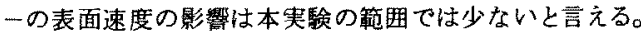
しかしながら，表面速度が数メートル以下になると，分

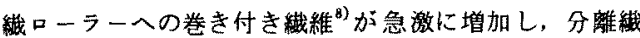

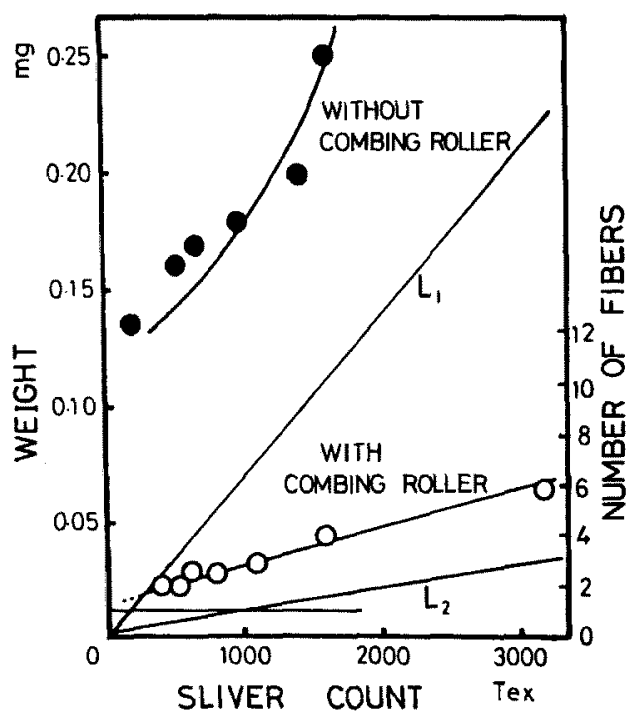

(A)

Fig. 3 (A) Relation between the input sliver count and the weight of separated fiber assembly.

$L_{1}$ : Number of fibers calculated from the ratio of surface velocity of combing roller to that of input roller.

$L_{2}$ : Number of fibers calculated from the ratio of air velocity to the surface speed of input roller. 


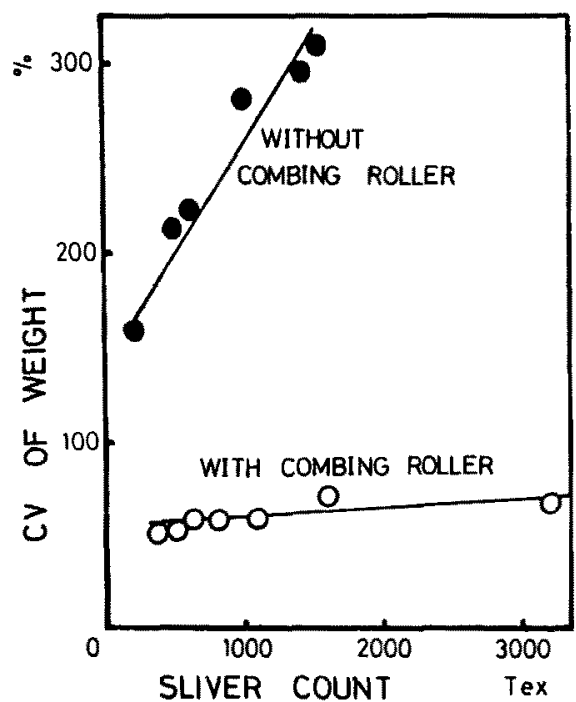

(B)

Fig. 3 (B) Relation between the input sliver count and the coefficient of variation in the separated fiber weight.

Surface velocity of input roller: $0.024 \mathrm{~m} / \mathrm{sec}$ Surface velocity of combing roller: $17.26 \mathrm{~m} / \mathrm{sec}$ Air velocity: $117 \mathrm{~m} / \mathrm{sec}$

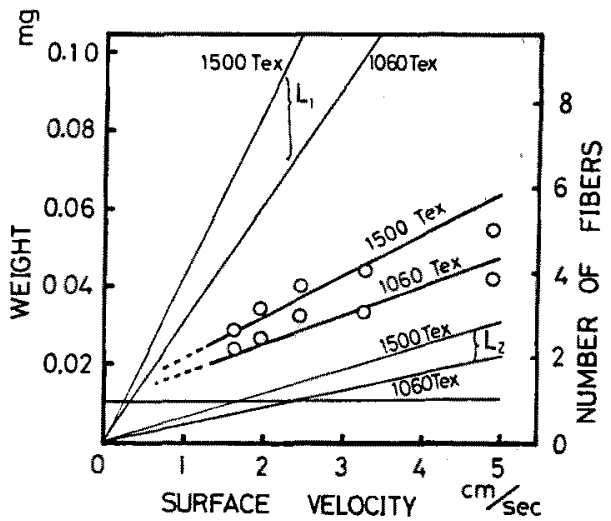

Fig. 4 Relation between the surface velocity of input roller and the weight of separated fiber assembly.

$\mathrm{L}_{1}$ : Number of fibers calculated from the ratio of surface velocity of combing roller to that of input roller.

$\mathrm{L}_{2}$ : Number of fibers calculated from the ratio of air velocity to the surface speed of input roller.

Surface velocity of input roller: $0.024 \mathrm{~m} / \mathrm{sec}$ Surface velocity of combing roller: $17.26 \mathrm{~m} / \mathrm{sec}$ Air velocity: $117 \mathrm{~m} / \mathrm{sec}$

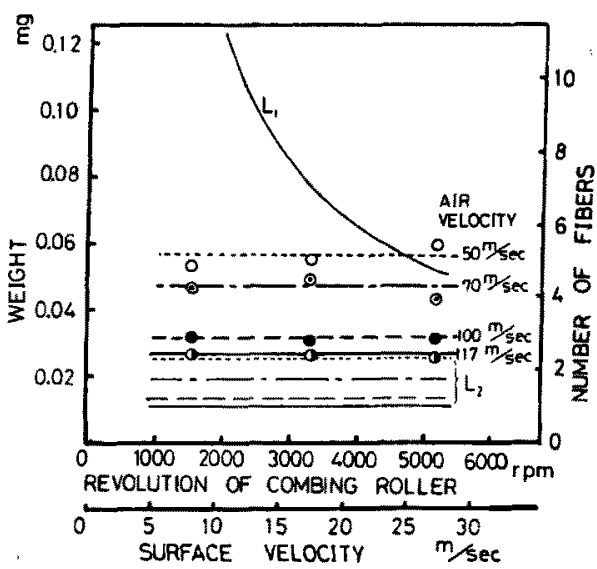

Fig. 5 Relation between the surface velocity of combing roller and the weight of separated fiber assembly.

$L_{1}$ : Number of fibers calculated from the ratio of the surface velocity of combing roller to that of input roller.

$\mathrm{L}_{2}$ : Number of fibers calculated from the ratio of air velocity to the surface speed of input roller.

Sliver count: 1060 tex

Surface velocity of input roller: $0.024 \mathrm{~m} / \mathrm{sec}$

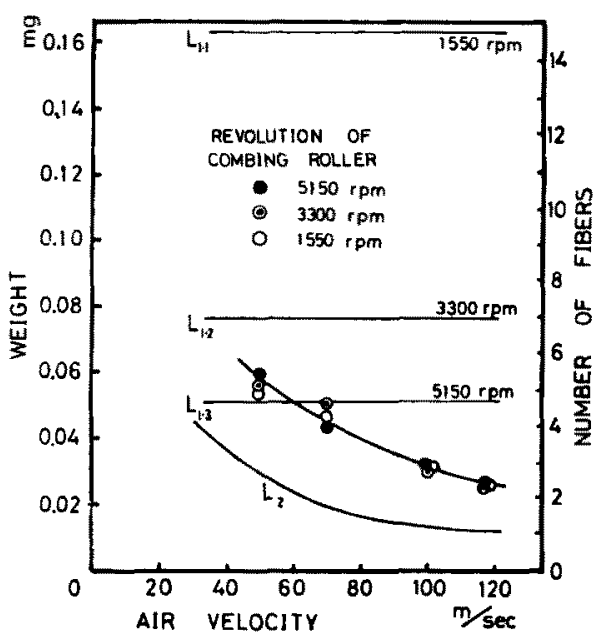

Fig. 6 Relation between the air velocity and the weight of separated fiber assembly.

$\mathrm{L}_{1 \cdot 1}, \mathrm{~L}_{1 \cdot 2}, \mathrm{~L}_{1 \cdot 3}$ : Number of fibers calculated from the surface velocity of combing roller to that of input roller.

$\mathrm{L}_{2}$ : Number of fibers calculated from the ratio of air velocity to the surface speed of input roller.

Sliver count: 1060 tex

Surface velocity of input roller: $0.024 \mathrm{~m} / \mathrm{sec}$ 
維集団の重量变動が增大し，分雄が不正常になる。この 点についてはさらに詳細な央験と解析が必要である。

図6 は撗軸に吸引風速をとって図5を書き改めたもの てある。吸引風速の增加とともに分離䄉維集団の大きさ は減少して㧍り，供給口ーラ一上吸引風速の速度比から 計算した $L_{2}$ 曲線と同様の傾向を示している。図5，6の 結果より，分離絿維重量に及ぼす影埄は吸引風速がとく に顕著であり，分緎ローラ一の回転数には美が認かられ なかった。本報告は分離の程度について検討したもので

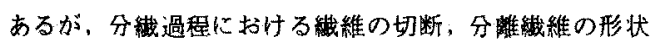
む重要な問題であり，分裁ローラーの効果はこれらを総 合して論ずることが望ましい。

\section{2 周期的な太さむらをもつスライバの分雖}

分織口ーラーによってスライバを開䄉・分離した場合， 供給スライバのむらがどのように変化するかを調べるた めに，前報と同琭な方法で周期的な太さむらをむつスラ イバを作成し分㸢した。スライバの波長は $10 \mathrm{~cm}$ と一定 にし，振幅が種々買なるスライバを分離した。記録紙を 单位時間 $(0.2 \mathrm{sec})$ に区切り，この時間に分離する維維

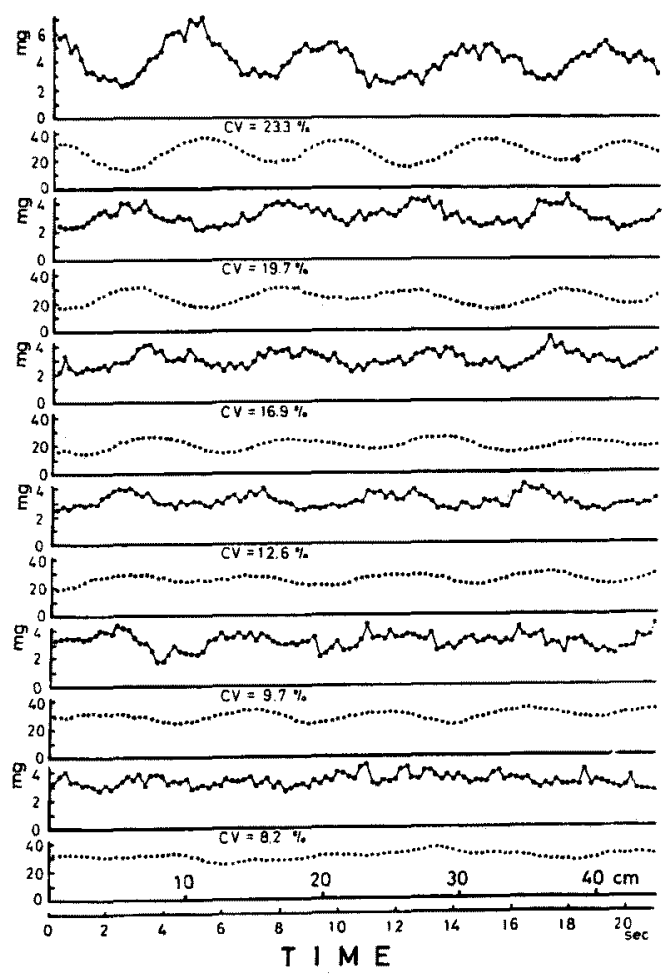

Fig. 7 Variations in the weight (....) of fiber assemblies separated per unit time $(0.2 \mathrm{sec})$ and the input sliver irregularity $(\ldots \ldots \ldots)$.
集団の全重量を計算しプロットした。図7にその結果を 示す。分晟重量の時間的変化に対応して供給スライバの むら曲線を示してある。種々の振幅の試料を同時に比較 した。眓より，供給スライバの太さに応じて分離重量も 変化している。振幅が小さくなると，その対応が明白に は認めにくくなる。

図 8 は分離個数の時間的変化を示す。重量变化の場合 と同様であり，供給スライバの太さ変化と全く同じでな く，周期成分が雪んだ形となっている。すなわち，周期 成分の他に，分䧹によって発生するランダム成分が付加 された形状を示す。

このような時間的な変動現象を自己相関関数によって 解析した。データ数の関係で系列相関係数 ${ }^{8)}$ を計算した。 図 9 は供給スライバ太さのコレログラムである。な㧍， 計算した結果の一部を図示した。供給スライパの变動の 大部分が正弦波状の周期成分である。

図10は分離織維集団重量のコレログラムを示したもの である。供給スライバと同様の周期成分が認められるが， 供給スライバと比較するとランダム成分の大輻な增加が

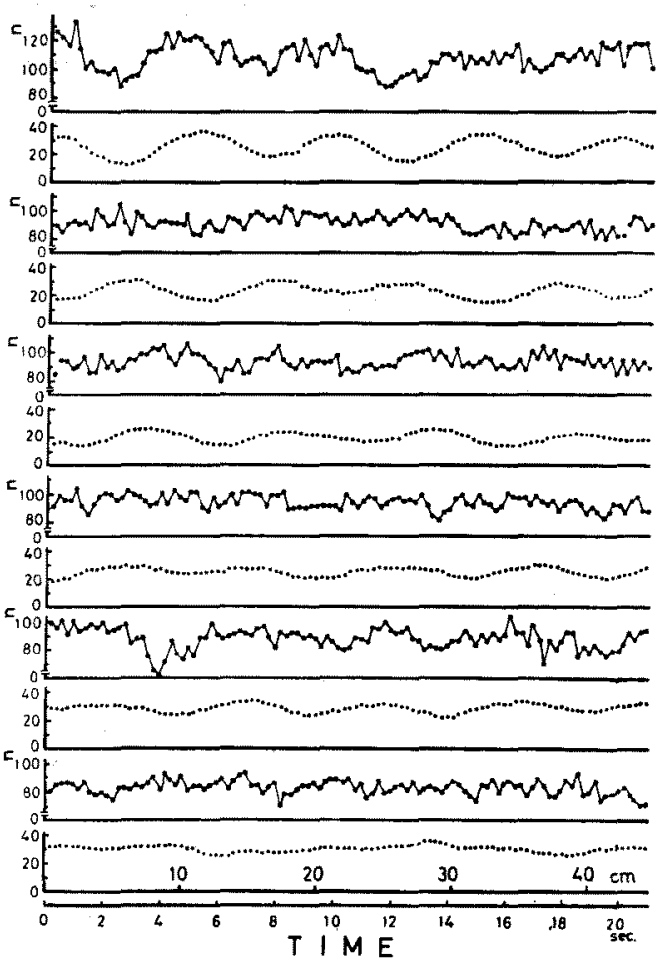

Fig. 8 Variations in the number ( $\ldots$ ) of fiber assemblies separated per unit time and the input sliver irregularity $(\ldots \ldots \ldots)$. 


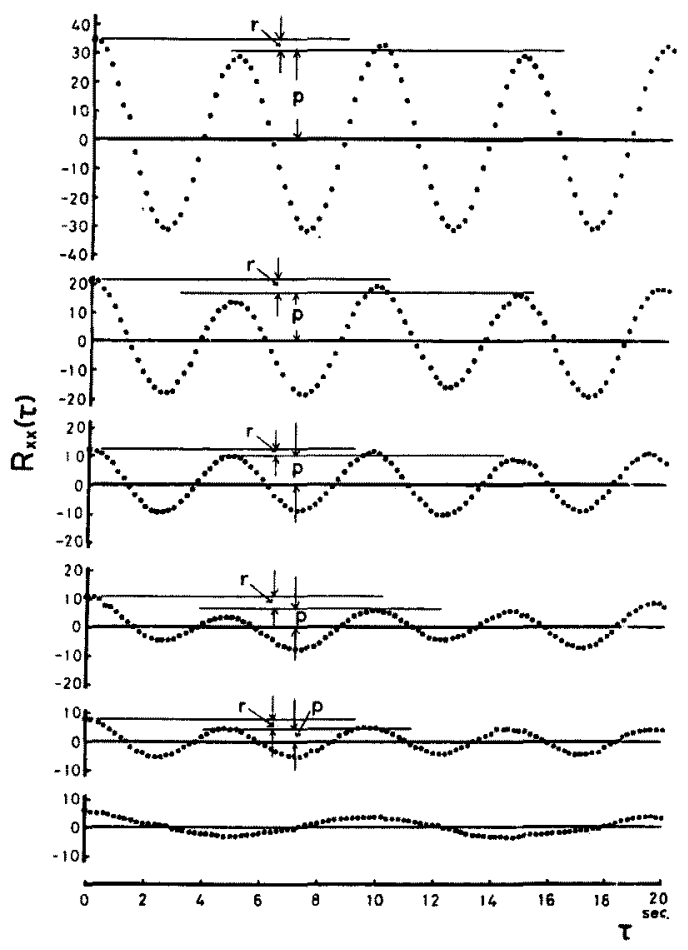

Fig. 9 Auto correlation functions of input sliver irregularity.

$\mathrm{r}$ : Random variation $\mathrm{p}$ : Periodic variation

認められる。単純分離の場合のコレログラムの周期成分 の形状が大きな昰を示す ${ }^{10)} の に$ 对し，分織ローラーの場 合には歪がほとんど認められない。

以上のように，いずれの場合も分傩後には供給スライ バが有していた周期成分のほかに，あらたなランダム成 分が付加した形となっている。そこで，変動成分中で ンダム成分や偽期成分が分離によってどの上うに变化す るか調べた。図11はその結果をまとめて示したもので ある。横軸に供給スライバ中て周期成分の占める割合を とり，轵軸には分離後に拉ける周期成分の占める割合を とったものである。図中 $45^{\circ}$ の勾配をむつ斜めの直線は 分離によってランダム成分と周期成分の比率が変化しな い場合の限界であって，実際の結果はこの線より下側に 存在する。すなおち，供給スライバが有していた䖝期成 分は分離によるあらたなランダム成分の発生によって相 対的に減少している。これは分㬦に拈ける大きな特改の 一つである。図に単純分離と分紻ローラーの両者の結果 が示してある。単純分離は分緎口ーラーよりも下に位置 している。すなるち，分離によって発生するランダム成 分が大きく，周期成分が相対的に减少する程度は単純分

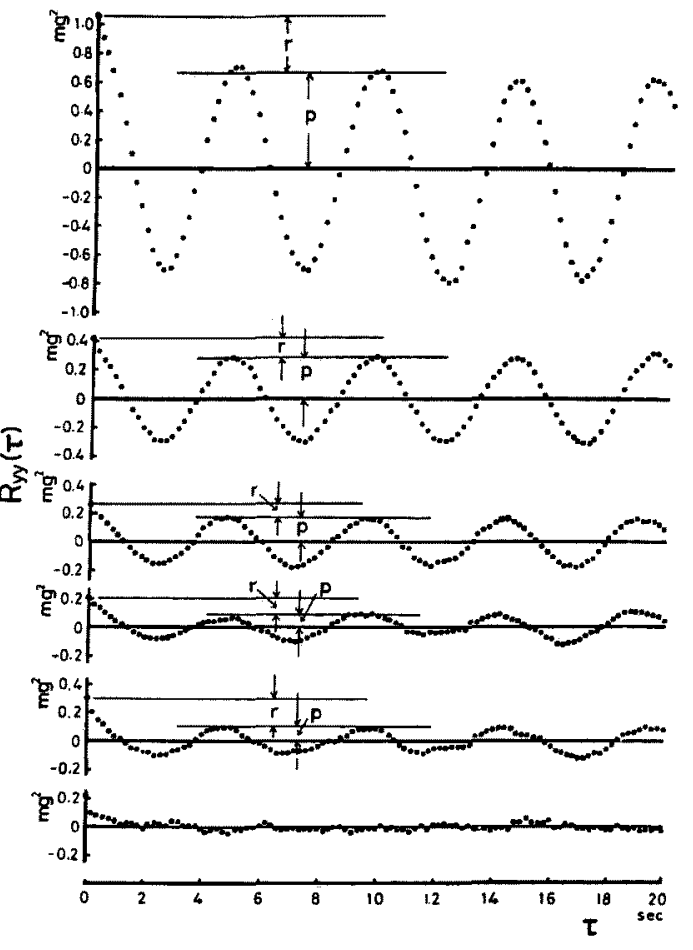

Fig. 10 Auto correlation functions of the weight of separated fiber assembly.

$r$ : Random variation $\mathrm{p}$ : Periodic variation

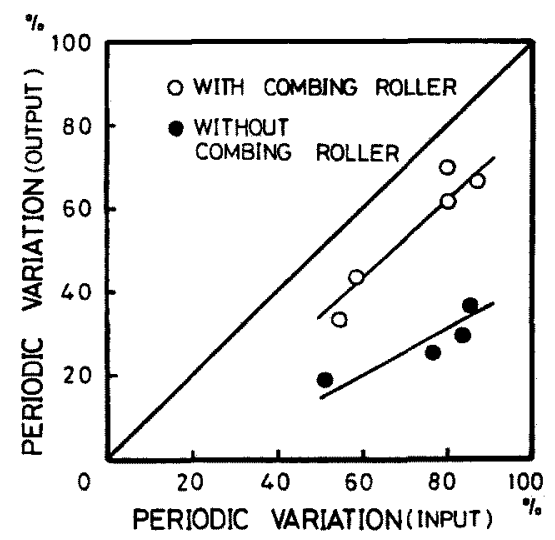

Fig. 11 Change of periodic variation $\%$ by separation.

\section{雕の方が大いことを意味している。}

大きなランダム成分のあらたな発生はそれ自身非常に 特敞的で効果的な現象である。しかしながら、コレロク ラムで $=0$ の值すなわち分散の值は図 12 に示すよう に，分織ローラーの場合はいずれのむらにおいても小さ 
く, $1 \mathrm{mg}^{\mathrm{9}}$ 以内であるが，単純分晟の場合注非常に大き く，100 $\mathrm{mg}^{2}$ 程度となって扔り，分離重量は大きな変動 を有する。

周期むらの振幅一定で波長を变化させた場合，本実験 の波長笽囲ではとくに頭著な傾向は認められなかった。

以上は時間間隔を 0.2 秒に区切り，その間で分離する 重量を求文， 0.2 秒間の変動を計算した結果であるが， 分離阵維集団 1 個每の重量を求めたデータより 1 個当り

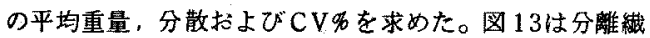
雓集団の 1 個当りの平均重量を示したものである。すて に、スライバ太さが分離に及㳯す影響で述べたように， 分織ローラーの場合は単純分離に比較して $1 / 10$ 程度に

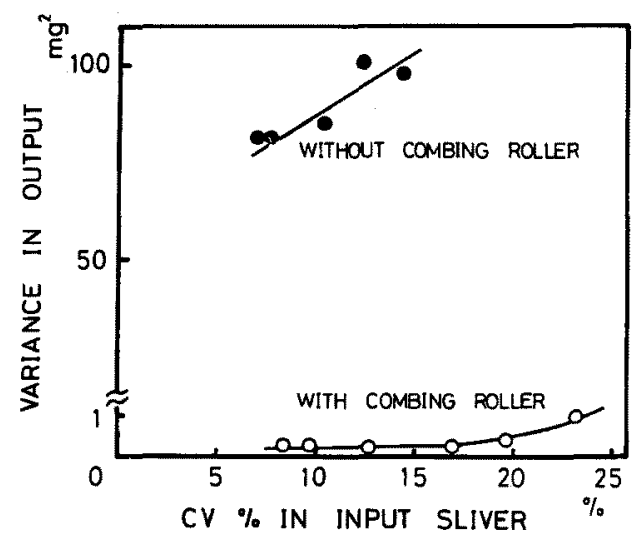

Fig. 12 Relation between the input sliver irregularity and the variance in the weight (per unit time) of output fiber assembly.

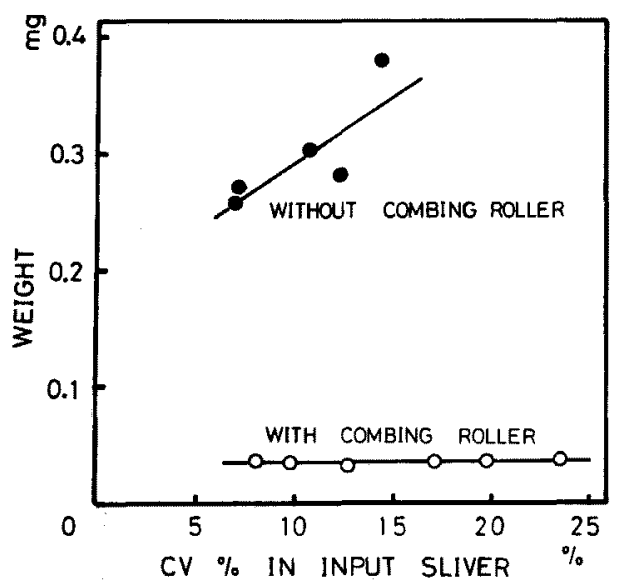

Fig. 13 Relation between the input sliver irregularity and the weight of individual fiber assembly.
小さくなっている。また，分緎ローラーの場合には供給 スライパむらが変化しても平蚐重量は変化しないが， 単純分離の場合には大きくなる。図14は分﨎緎維集団 の重量の分散を示したものである。平均重量の場合と同 㥞に大きな善が羿められる。図 15 は図13，図14から CV名を計算して図示したものである。図 3(B)の結果 と同様に分㵶ローラーの場合には $50 \%$ 程度でり，単純 分離の場合は $300 \%$ と夫き値を示している。

\section{3 供給スライバ太さと分離繊維集団重壹しの 相互相関}

供給スライパの太さむらと分離㵶維集団重量変化がど の上うな関係にあるかを調べるために相互相関関数を求

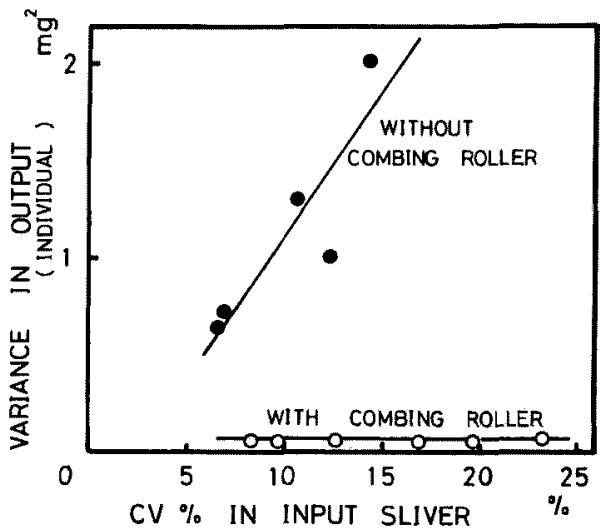

Fig. 14 Relation between the input sliver irregularity and the variance in the output weight (individual) of separated fiber assembly.

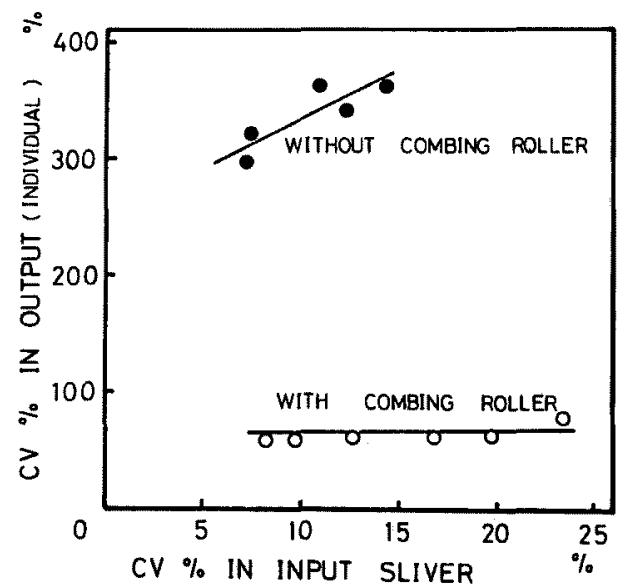

Fig. 15 Relation between the input sliver irregularity and the $\mathrm{CV} \%$ in the output weight (individual) of separated fiber assembly. 

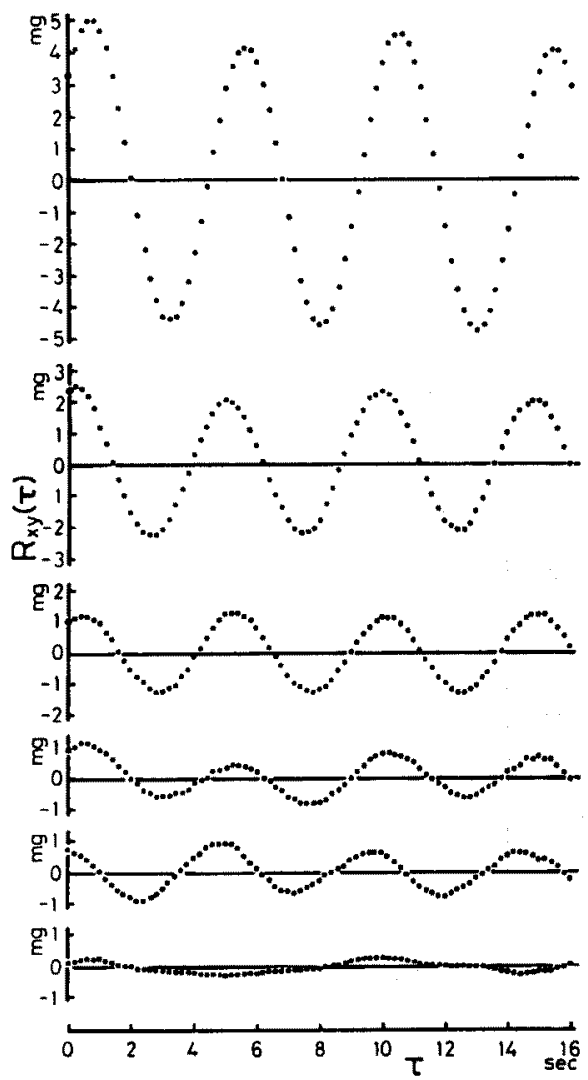

Fig. 16 Cross correlation functions between the input sliver irregularity and the weight variation in the separated fiber assembly.

めた。図16 種々の振幅のむらについてまとめて示し たものである。自己相関関数と同様に正弦波状の周期関 数を示す。て二0において極大を示さないのは，むら曲 線と分踓記録との対応にずれを有していたためである。 図のように，むらの振幅が小さくなるにしたがって相互 相関の強さは堿少する。 $\tau=0$ 付近ての極大点の值を規 格化し，供給スライバむらを横軸にとって，その值を示 したのが図 17 であ。供給スライハさむらが大きい場合 には相互相関係数は大きく，むらが小さくなると相関の 強さが弱くなる。この結果は，前述したように周期むら の振幅が小さいほど周期成分の相対的诚少が大きいこと 加ら理解される。単純分離の結果と比較した場合，分㵶 ローラーによる結果の力が相関が绌い。すなわち，分緎 ローラーの場合には，単純分離の場合よりも供給スライ ハのむらを忠実に分離する傾向がある。

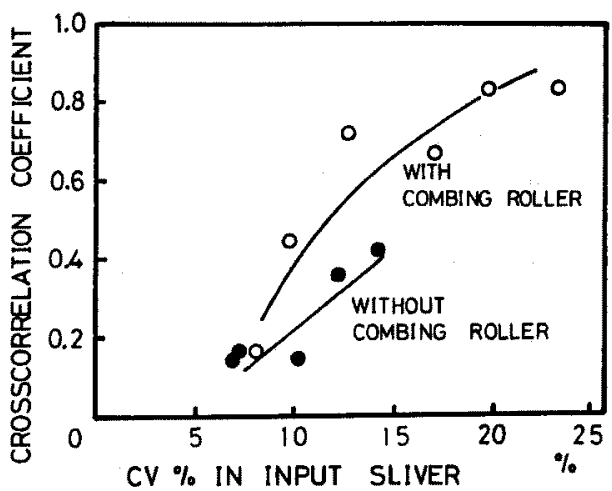

Fig. 17 Effect of input sliver irregularity on the cross correlation coefficient between the input sliver irregularity and the weight variation in the separated fiber assembly.

\section{4. 結受}

分織ローラ一を用いた場合に扔けるスライバの分䄉状 態を連続的に検出し，結果を統計的に解析した。すなわ ち，スライバ太さ，供給速度，分織口ーラーの回転数お よび吸引笑流速度が分離効果に及ぼす影響を明らかにし た。また。周期むらをもつスライパを分離し相関関数な どによりむらと分離の関係を究明した。

得られた結果はつぎのようである。

（1）分䋞ローラーを設置した場合，分離紻維集団の重 量および変動は吸引気流のみによる単純分離と比較して 非常に小さい。

（2）供給スライバが太いほど，また供給ローラーの表 面速度が大きくなるほど分離重量は大きくなる。

（3）分䄉口ーラーの表面速度の变化よりも吸引気流速 度の力が分離重量に大きな影䒁を及ぼす。

（4）分離によって供給スライトになかったランダム成 分があらたに発生し，供給スライドが有していた周期成 分は相対的に減少する。この程度は単純分離の方が大き い。

付記：本研究の1 部は昭和 49 年 10 月瀻維学会秋季 研究発表会 (岐皁) 扝よび昭和 49 年6月織機学会年次大 会 (大阪)で発表した。

\section{文 献}

1）宇野 稳，塩見昭，帕田信義；䋐機誌，21， $\mathrm{T} 283$ (1968)

2) J. Lüenschloß, L. Coll-Tortosa; Melliand Textilber, 49,570 (1973)

3) J. Lienschloß, L. Coll-Tortosa, T.T. Phoa; Chemiefasern, 24, 355 (1974) 
4) 近田富土雄, 黑崎新也, 加藤久明, 横井蛞之; 践 学誌, 31, T-495 (1975)

5) 前掲 4)

6) 前揭 4)

7) 森川孝士；繊機誌， 27，P 476(1974)

8）井谷和十郎，伊垣敬二，坂野忠司，岩本正治；緎
機学会, 昭和 47 年年次大会研究発表会講演 要旨 集，P 25(1972)

9）東京工美大学統計工学研究会編; 「統計工学ハン ドブック」，技報堂，P 118(1954)

10) 前提 4)

（昭和 50 年 4 月 15 日受理）

\title{
主成分分析によるアクリル繊維の抗ピル性 と原綿物性の関係についで
}

\author{
東レ株式会社織維研究所青谷寞 \\ RELATION BETWEEN PILLING-TENDENCY AND TENSILE PROPERTIES
OF ACRYLIC FIBER BY PRINCIPAL COMPONENT ANALYSIS
}

By Hiroshi Aotani

Fibers and Textiles Research Labs., Toray Industries, Inc., 1515 Masaki-cho, lyogun, Ehime Prefecture, Japan

The relation between pilling tendency and tensile properties of staple fiber was studied by rearranging and analysing a lot of data which had been carried out by trial and error.

Principal component analysis was used as a statistical analysis. It was found that pilling tendency by ICImethod (pill grade) is composed of three principal components as shown below.

\begin{tabular}{c|l|c|c}
\hline Principal component & Physical meaning & $\begin{array}{l}\text { Tensile properties } \\
\text { of staple fiber }\end{array}$ & $\begin{array}{c}\text { Percentage of } \\
\text { contribution (\%) }\end{array}$ \\
\hline $\mathrm{X}_{1}$ & shear strength & $\mathrm{KT}, \mathrm{LT}, \mathrm{LE}$ & 74 \\
\hline $\mathrm{X}_{2}$ & tensile strength & $\mathrm{DT}$ & 16 \\
\hline $\mathrm{X}_{3}$ & shape factor (?) & $\mathrm{d}(?)$ & 5 \\
\hline
\end{tabular}

Principal component No. 1 is related to shear strength such as knot tenacity (KT), loop tenacity (LT) and loop elongation (LE), and its percentage of contribution to pilling tendency is found the largest.

Consequently, pilling tendency can be represented by a few tensile properties of staple fiber such as KT, LT and LE. Furthermore, rate constant of pill wearing-off $\left(k_{2}\right)$ by SF-pill-tester shown in the previous report holds good correlation to principal component No. 1.

(Received April 15, 1975)

*この報文を「抗ピルアクリル㵶維に関するる研究(第 3 報), Studies on the anti-pilling acylic $\mathrm{fi}^{-}$ bers (Part III )」とする。

**現在の所属; 東レ株式会社技術研究企画部(東京都中 央区日本橋室町 2-2)

Present adress;R \& D Planning Dept, Toray Industries Inc., 2-2 Nihonbashi Muromachi Chuoku, Tokyo, Japan.

\section{1. 緒言}

抗ピル性アクリル絨維の開発を目的とした研究はかな り長期にわたって行なわれ，数多くの具体的な手法が報 告されている゙2。しかしこれまでの研究の進め方を振り 返ってみると，単に重合一紡系一紡績一編成一抗ピル性 評価という操作を試行錯䛊でくり返していたにすぎず， 抗ビル性を村与するための原綿物性，抗ピル性と紻維構 